\title{
AKTIVITAS PENANGKAPAN DAN DISTRIBUSI UDANG GALAH (Macrobrachium rosenbergii) DI DAERAH ALIRAN SUNGAI KAPUAS, KALIMANTAN BARAT
}

\author{
Samuel1) dan Siti Nurul Aida1) \\ 1) Peneliti pada Balai Riset Perikanan Perairan Umum, Mariana-Palembang \\ Teregristrasi I tanggal: 7 September 2007; Diterima setelah perbaikan tanggal: 13 Mei 2008; \\ Disetujui terbit tanggal: 15 Mei 2008
}

\begin{abstract}
ABSTRAK
Suatu riset yang bertujuan untuk mendapatkan data dan informasi tentang aktivitas penangkapan dan distribusi udang galah (Macrobrachium rosenbergii) di daerah aliaran Sungai Kapuas, Kalimantan Barat telah dilakukan dari bulan Juni sampai dengan Desember 2005. Riset dilaksanakan dengan metode survei dengan cara mendatangi lokasi-lokasi tempat ada aktivitas penangkapan udang galah (Macrobrachium rosenbergii). Frekuensi survei 2 kali pada musim kemarau dan 2 kali pada musim hujan. Wilayah perairan yang disurvei adalah daerah aliaran Sungai Kapuas dalam Kabupaten Pontianak, Kota Pontianak, Kabupaten Sanggau, dan Kabupaten Sintang. Data dianalisis dengan metode deskriptif dan tabulasi. Dari survei ditemukan 9 jenis alat tangkap yang digunakan nelayan untuk menangkap udang galah (Macrobrachium rosenbergii) yaitu pancing, rawai, bubu, jala, jaring, blad, rompong, stroom, dan pukat rantau. Catch per unit of effort terkecil terjadi pada alat tangkap bubu yaitu 1,39 g per per unit per jam, terbesar adalah jala yaitu 416,67 g per unit jala per jam. Intensitas penangkapan terlihat dominan di perairan bagian hilir mencakup wilayah Kabupaten dan Kota Pontianak. Distribusi ukuran bobot individu udang galah (Macrobrachium rosenbergii) yang banyak tertangkap oleh nelayan (nilai modus) dari 4 kali survei bervariasi antara 17,73 sampai dengan 40,00 g (Kabupaten Pontianak); 19,31 sampai dengan 47,01 g (Kota Pontianak), 17,79 sampai dengan 45, $35 \mathrm{~g}$ (Kabupaten Sanggau), dan antara 25,08 sampai dengan 85,52 g (Kabupaten Sintang). Kualitas air pada habitat tempat udang tertangkap di daerah aliaran Sungai Kapuas dalam batas-batas yang layak untuk mendukung kehidupan ikan dan udang.
\end{abstract}

KATAKUNCI: udang galah, daerah aliaran Sungai Kapuas, aktivitas penangkapan, distribusi ukuran

ABSTRACT: Capture activities and distribution of giant freshwater prawn in Kapuas River, West Kalimantan. By: Samuel and Siti Nurul Aida

A study aimed to obtain recent data and information about capture activities and distribution of giant freshwater (Macrobrachium rosenbergii) prawn in Kapuas River, West Kalimantan was conducted from June to December 2005. Survey method was used in each research stations that are Pontianak district, Pontianak City, Sanggau, and Sintang districts. The stations were selected based on fishing activities and habitat condition. Field survey was completed by conducting 4 times surveys including dry and rainy seasons. Data collected were analyzed by using tabulation and descriptive method. The results showed that there were 9 types of fishing gears commonly used to catch giant freshwater (Macrobrachium rosenbergii) prawn. These fishing gears were : hook and line, long line, pot traps, cast net, gill net, barrier traps, surrounding net, electrical fishing, and surrounding net. Catch per unit effort of the cast net was the highest (416,67 gr per unit per hour, whereas, pot trap was the lowest (1,39 $g$ per unit per hour). Water quality in each stations indicated suitable for aquatic organisms. The capture intensity showed that in downstream (Pontianak District and Pontianak City) was more dominant than in upstream (Sanggau and Sintang Districts). Distribution of weight based on modus indicated variation in each stations, which are 17.73 to $40.00 \mathrm{~g}$ (Pontianak District), 19.31 to $47.01 \mathrm{~g}$ (Pontianak District), 17.79 to $45.35 \mathrm{~g}$ (Sanggau District), and 25.08 to $85.52 \mathrm{~g}$ (Sintang District).

KEYWORDS: $\quad$ giant freshwater prawn, Kapuas River Basins, capture activities, size distribution

\section{PENDAHULUAN}

Udang galah (Macrobrachium rosenbergii) merupakan jenis udang air tawar yang mempunyai nilai ekonomis penting, baik sebagai konsumsi masyarakat maupun sebagai komoditi eksport. Penangkapan jenis biota ini pada beberapa perairan umum di Indonesia sudah demikian intensif. Sebagai contoh kasus yang terjadi di perairan Sungai Lempuing, Kabupaten Ogan Komering Ilir, dan 
Sumatera Selatan. Pada tahun 1983 dan periode tahun sebelumnya, udang galah (Macrobrachium rosenbergii) merupakan komoditas andalan bagi pendapatan nelayan karena harga lebih tinggi dari ikan dan hasil tangkapan tergolong tinggi. Dari tahun 1983 sampai dengan 1990, hasil tangkapan udang galah (Macrobrachium rosenbergii) di perairan Sungai Lempuing menunjukkan penurunan rata-rata 12,5\% per tahun (Utomo, 1997) dan sampai tahun 2006, udang galah (Macrobrachium rosenbergii) sudah sulit didapat.

Berbagai faktor penyebab turun produksi hasil tangkapan udang galah antara lain oleh induk-induk udang yang telah dibuahi banyak tertangkap pada bulan Pebruari sampai dengan Maret oleh berbagai alat tangkap seperti langgian (scoop net), tuguk (filtering device), empang lulung (barrier traps), bengkirai bilah (poot traps), dan pancing (hook and lines) sehingga keberadaan udang-udang muda dari hasil pemijahan menurun (Utomo et al., 2002). Penyebab lain di samping aktivitas tersebut adalah faktor lingkungan seperti penurunan kualitas air, meskipun penangkapan yang intensif dengan berbagai cara menangkap menjadi penyebab yang utama. Oleh karena itu, komoditas ini merupakan komoditas eksport yang dapat memasukkan devisa bagi negara dari sektor perikanan, maka kestabilan produksi di perairan umum perlu tetap terjaga. Untuk itu, riset aktivitas penangkapan dan distribusi udang galah di perairan umum dilakukan.

Hasil tangkapan udang galah (Macrobrachium rosenbergii) di perairan umum Kalimantan Barat pada kwartal I (bulan Januari sampai dengan Maret 2003) 89,2 ton $(36,65 \%)$, sedangkan pada kwartal II (bulan April sampai dengan Juni), kwartal III (bulan Juli sampai dengan September), dan kwartal IV (bulan Oktober sampai dengan Desember) masing-masing 85,9 ton $(34,72 \%), 41,2$ ton $(16,65 \%)$, dan 31,1 ton $(12,57 \%)$. Sebagaimana terjadi di perairan Sungai Lempuing Sumatera Selatan, periode penangkapan udang galah terlihat ada kesamaan di mana hasil penangkapan udang galah (Macrobrachium rosenbergii) pada kwartal I (bulan Januari sampai dengan Maret) tergolong banyak. Periode tersebut banyak tertangkap induk-induk udang galah yang telah mengandung telur (Samuel et al., 1991). Di samping itu, harga udang galah (Macrobrachium rosenbergii) di Propinsi Kalimantan Barat menduduki ranking ke-2 setelah harga ikan betutu (Oxyeleotris marmorata), kemudian diikuti oleh harga ikan jelawat (Leptobarbus hoeveni) dan belida (Notopterus chitala) (ranking 3 dan 4). Dengan demikian, udang galah
(Macrobrachium rosenbergii) merupakan komoditas penting perairan umum yang perlu dijaga kelestarian.

Riset ini bertujuan untuk mendapatkan data dan informasi terkini tentang aktivitas penangkapan dan distribusi udang galah (Macrobrachium rosenbergii) di daerah aliran Sungai Kapuas, Kalimantan Barat. Kajian aktivitas penangkapan dilakukan untuk mengetahui jenis alat tangkap, dan habitat udang galah (Macrobrachium rosenbergii). Pengamatan distribusi udang galah (Macrobrachium rosenbergii) dilakukan untuk mengetahui tentang distribusi ukuran udang galah (Macrobrachium rosenbergii) yang tertangkap oleh nelayan di setiap lokasi pengamatan dan distribusi aspek reproduksi yaitu tingkat kematangan gonad, fekunditas, dan diameter telur. Informasi yang diperoleh diharapkan dapat menjadi bahan masukan berguna bagi pengelolaan sumber daya udang galah (Macrobrachium rosenbergii) di perairan umum Sungai Kapuas, Kalimantan Barat.

\section{BAHAN DAN METODE}

Riset dilakukan di daerah aliran Sungai Kapuas, Kalimantan Barat dengan cara survei di lokasi-lokasi pengamatan yang ditentukan berdasarkan pada ada aktivitas penangkapan udang galah (Macrobrachium rosenbergii). Obyek yang diamati atau diukur dalam aktivitas penangkapan udang galah (Macrobrachium rosenbergii) adalah jenis, spesifikasi, dan ukuran alat tangkap, metode atau cara penangkapan, serta lokasi atau habitat perairan tempat tertangkap udang galah (Macrobrachium rosenbergii).

Parameter yang diukur meliputi sebaran frekuensi ukuran, kuantitas hasil tangkapan, dan upaya penangkapan (catch per unit of effort), dan beberapa parameter kualitas air seperti suhu, kecerahan air, $\mathrm{pH}$-perairan, kadar oksigen terlarut, dan kadar $\mathrm{CO} 2-$ bebas diukur berdasarkan pada pedoman yang dikatakan oleh APHA (1988) tertera pada Tabel 1.

\section{Stasiun dan Waktu Pengamatan}

Udang galah (Macrobrachium rosenbergii) merupakan biota air tawar yang dalam siklus hidup memerlukan 2 habitat yaitu habitat air tawar dan air payau. Pada fase dewasa hidup sebagian besar di air tawar, sedangkan pada fase larva memerlukan air payau. Dari siklus hidup udang galah (Macrobrachium rosenbergii) tersebut, maka penentuan stasiun pengamatan di daerah aliran Sungai Kapuas dibagi atas 4 wilayah kabupaten atau kota (Gambar 1) yaitu a) perairan Sungai Kapuas yang berada dalam 
Kabupaten Pontianak di wakili oleh Daerah Jungkat dan Sungai Kakap. Di ke-2 daerah tersebut kondisi air Sungai Kapuas tergolong air payau terus ke arah hulu sampai dengan perbatasan antara Kabupaten Pontianak dan Kota Pontianak; b) perairan Sungai Kapuas dalam wilayah Kota Pontianak. Airnya tawar, namun pada musim kemarau, air terkadang menjadi payau; c) perairan Sungai Kapuas dalam Kabupaten Sanggau, di mana kondisi air telah tawar; d) perairan Sungai Kapuas dalam wilayah Kabupaten Sintang. Perairan Kapuas dalam Kabupaten Sintang ini secara menyeluruh merupakan perairan tawar.

Tabel 1. Parameter fisika kimia perairan yang diukur serta metode atau alat untuk mengukur Table 1. Physico chemical parameters measured and methods or tools for its measurement

\begin{tabular}{cll}
\hline No. & \multicolumn{1}{c}{ ParameteriParameters } & \multicolumn{1}{c}{ Metode atau alatiMethods or tools } \\
\hline 1. & Temperatur $\left({ }^{\circ} \mathrm{C}\right)$ & Termometer air raksa \\
2. & Kecerahan $(\mathrm{cm})$ & Piring secchi (secchi disk) \\
3. & Substrat dasar & Ekman dredge \\
4. & pH-air (unit) & $\mathrm{pH}$ - indikator universal \\
5. & Oksigen $\left(\mathrm{O}_{2}\right)$-terlarut $(\mathrm{mg} / \mathrm{l})$ & Titrimetri \\
6. & Karbondiokida $\left(\mathrm{CO}_{2}\right)$-bebas (mgil) & Titrimetri \\
\hline
\end{tabular}

Propinsi Kalimantan Barat

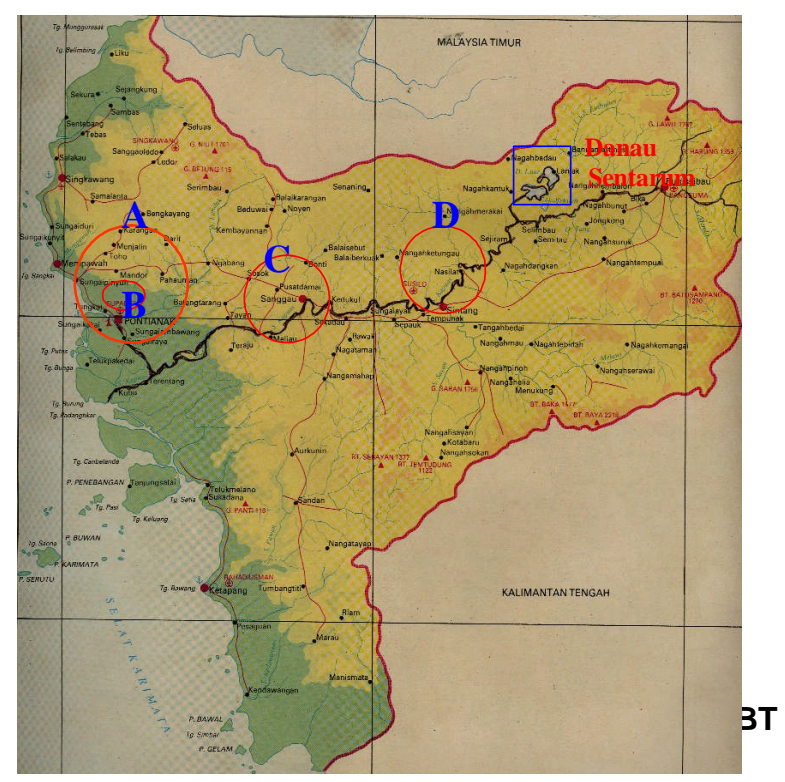

Keterangan/Remarks:

$2^{\circ}$

$A=$ Lokasi riset dalam wilayah Kabupaten Pontianak

LU $\quad B=$ Lokasi riset dalam wilayah Kota Pontianak

$\mathrm{C}=$ Lokasi riset dalam wilayah Kabupaten Sanggau

$\mathrm{D}=$ Lokasi riset dalam wilayah Kabupaten Sintang

$0^{\circ}$

KT

$2^{\circ}$

LS

Gambar 1. Peta lokasi riset aktivitas penangkapan dan distribusi udang galah (Macrobrachium rosenbergii) di daerah aliran Sungai Kapuas, Propinsi Kalimantan Barat.

Figure 1. Map of the research station for the research on fishing activities and size distribution of giant freshwater (Macrobrachium rosenbergii) prawn in the Kapuas River, West Kalimantan.

Lokasi pengamatan di bagian hilir Kabupaten Pontianak, baik di Daerah Jungkat maupun di Daerah Sungai Kakap banyak terdapat hutan bakau, sedangkan di Daerah perkotaan Pontianak sudah merupakan wilayah pemukiman padat penduduk dan industri. Daerah pengamatan di Kabupaten Sanggau dan Sintang didominasi oleh lahan hutan rawang yang kondisi baik. Survei dilakukan 4 kali yaitu 2 kali di musim kemarau (bulan Juni dan Agustus 2005) dan 2 kali di musim hujan (bulan Oktober dan Desember 2005).

\section{Pengumpulan Data}

Pengumpulan data terdiri atas 3 bagian yakni 1) data hasil tangkapan dan informasi tentang jenis, spesifikasi, ukuran, dan metode pengoperasian alat; 2) data panjang bobot, tingkat kematangan gonad, fekunditas, dan diameter telur; dan 3) data parameter kualitas perairan.

Pengumpulan data hasil tangkapan udang dan alat tangkap dilakukan langsung di lapangan dengan cara 
pengukuran dan pencatatan hasil tangkapan melalui wawancara pada nelayan yang dijumpai di lokasi pengamatan. Pada waktu wawancara dengan nelayan, dilakukan pula pengambilan contoh udang galah (Macrobrachium rosenbergii) yang tertangkap, diukur panjang bobot dan dicatat tingkat kematangan gonad. Untuk udang yang mengandung telur, maka udang tersebut diawet dengan larutan formalin dan selanjutnya diamati fekunditas dan diameter telura di laboratorium. Pengukuran parameter kualitas air dilaksanakan langsung di lapangan (in situ). Pengukuran parameter kualitas air yaitu suhu menggunakan termometer air raksa dengan skala $0,1^{\circ} \mathrm{C}$, kecerahan menggunakan keping sechiidengan ketelitian $1 \mathrm{~cm}, \mathrm{pH}$ menggunakan $\mathrm{pH}$ indikator universal, Kadar oksigen $\left(\mathrm{O}_{2}\right)$-terlarut, dan karbondioksida $\left(\mathrm{CO}_{2}\right)$-bebas menggunakan cara titrimetri. Pengukuran parameter kualitas air tersebut berpedoman pada buku petunjuk APHA (1988).

\section{Analisis Data}

Data dan informasi tentang aktivitas penangkapan dan hasil tangkapan (catch per unit of effort) per jenis alat tangkap dianalisis menggunakan metode tabulasi dan deskriptif. Distribusi ukuran udang galah (Macrobrachium rosenbergii) yang tertangkap dan ukuran diameter telur dianalisis menggunakan distribusi frekuensi dengan menerapkan kaidah Sturges (Ritonga, 1987) yaitu data hasil pengukuran panjang dan bobot serta hasil pengukuran diameter telur dibagi ke dalam beberapa kelompok (kelas) dengan rumus:

$$
K=1+3,322 \log N
$$

di mana:

$$
\begin{aligned}
& \mathrm{K}=\text { jumlah kelompok atau kelas } \\
& \mathrm{N}=\text { jumlah contoh }
\end{aligned}
$$

Untuk mencari jarak atau interval kelas digunakan rumus:

$$
\text { i (interval) }=\left(\mathrm{N}_{\mathrm{tt}}-\mathrm{N}_{\mathrm{tr}}\right) / \mathrm{K}
$$

di mana:

$$
\begin{aligned}
\mathrm{N}_{\mathrm{tt}}= & \text { nilai tertinggi yang terdapat dalam data hasil } \\
& \text { pengukuran } \\
\mathrm{N}_{\mathrm{tr}}= & \text { nilai terendah }
\end{aligned}
$$

Bagi udang yang mengandung telur yang telah dibuahi, pengamatan gonad dilakukan pada broodchamber yang terletak di antara kaki renang. Menurut Nikolsky dalam Mantel (1983), tingkat kematangan gonad udang yang telah dibuahi terbagi atas 4 bagian yaitu tingkat kematangan gonad $\mathrm{I}=$ telur bewarna kuning (baru dibuahi), kemudian meningkat menjadi berwarna jingga (tingkat kematangan gonad II), kecoklatan (tingkat kematangan gonad III), dan terakhir bewarna keabuabuan (tingkat kematangan gonad IV). Pada tahap akhir ini (tingkat kematangan gonad IV) telur sudah siap untuk menetas. Untuk mencari nilai rata-rata dan modus dari ukuran dan diameter telur udang galah tingkat kematangan gonad yang tertangkap digunakan rumus sebagai berikut:

$$
\begin{aligned}
& \text { Nilai rata-rata }\left(\mathrm{X}_{\text {rata2 }}\right)=(\text { ("FX)/N .................... (3 } \\
& \text { Nilai modus }(\mathrm{Mo})=\mathrm{Tb}+(\mathrm{d} 1 /(\mathrm{d} 1+\mathrm{d} 2)) \mathrm{i}
\end{aligned}
$$

di mana:

$$
\begin{aligned}
\mathrm{F}= & \text { frekuensi } \\
\mathrm{X}= & \text { nilai tengah } \\
\mathrm{N}= & \text { jumlah contoh } \\
\mathrm{Tb}= & \text { tepi bawah kelas yang memuat modus } \\
\mathrm{d} 1= & \text { selisih antara frekuensi kelas modus dengan } \\
& \text { frekuensi kelas sebelum } \\
\mathrm{d} 2= & \text { selisih antara frekuensi kelas modus dengan } \\
& \quad \text { frekuensi kelas sesudah } \\
\mathrm{i}= & \text { interval kelas }
\end{aligned}
$$

\section{HASIL DAN BAHASAN}

\section{Aktivitas Penangkapan Udang Galah (Macrobrachium rosenbergii)}

Penangkapan udang galah (Macrobrachium rosenbergii) di daerah aliran Sungai Kapuas terjadi sepanjang tahun. Penangkapan udang galah (Macrobrachium rosenbergii) pada umumnya dilakukan di tipe habitat perairan sungai yaitu di Sungai Kapuas dan anak-anak, mulai dari hilir sampai dengan ke hulu. Sembilan jenis alat tangkap yang digunakan nelayan untuk menangkap udang galah (Macrobrachium rosenbergii) di daerah aliran Sungai Kapuas pancing, rawai udang, bubu, jala, jaring atau pukat, empang atau blad, rompong atau rumpon, stroom menggunakan baterai accu dan pukat rantau. Dari 9 jenis alat tangkap tersebut, 8 jenis tergolong alat tangkap yang legal dan 1 alat tangkap yang menggunakan alat bantu stroom dengan alat tangkap udang berupa serok (scoope net) termasuk yang dilarang. Berdasarkan pada klasifikasi yang dikatakan oleh Brandt (1969), ke-9 jenis alat tangkap udang tersebut dapat dikelompokkan menjadi 6 bagian yaitu 1) fishing with lines yaitu penangkapan udang dengan menggunakan pancing (yang termasuk dalam bagian ini adalah pancing dan rawai udang); 2) fishing with traps yaitu penangkapan dengan menggunakan perangkap (bubu udang dan blad); 3) fishing with the drive in methods yaitu penangkapan dengan cara 
mengumpulkan udang atau ikan ke suatu tempat dan kemudian ditangkap (yang termasuk dalam bagian ini adalah rompong dan pukat rantau); 4) fishing with falling net gear yaitu penangkapan udang dengan cara menjatuhkan alat yang termasuk dalam bagian ini adalah jala; 5) fishing with gill nets yaitu penangkapan dengan menggunakan jaring (jaring insang); dan 6) fishing with lift nets yaitu penangkapan dengan cara mengangkat jaring, yang termasuk dalam bagian ini adalah serok atau sauk (scoope net) dengan alat bantu adalah stroom accu $2 \times 12$ volt. Penjelasan ke-9 alat tangkap tentang jenis, ukuran, cara, dan habitat tempat beroperasi adalah sebagai berikut:

\section{Pancing (Hook and Lines)}

Pancing yang digunakan nelayan ada 2 jenis yaitu a) pancing bergalah, panjang galah 3 sampai dengan $5 \mathrm{~m}$, terbuat dari bahan fiber dan dilengkapi alat penggulung. Tali pancing dari bahan senar no. 2 dan mata pancing terbuat dari kawat baja dan dilengkapi pemberat dari timah. Cara kerja menggunakan perahu diawaki 1 sampai dengan 2 orang. Pancing dipegang dan tali pancing diulur sampai dengan ke dasar perairan sampai dengan mata pancing dan umpan berada di atas dasar perairan. Umpan menggunakan cacing nipah, cacing tanah, dan anak udang. Habitat penangkapan di perairan sungai bagian tepi yang terdapat banyak tumbuh-tumbuhan; b) pancing gulung, alat penggulung terbuat dari tabung bambu yang dipotong sepanjang 12 sampai dengan $15 \mathrm{~cm}$ dengan diameter 8 sampai dengan $11 \mathrm{~cm}$. Tali pancing dari senar no.2, mata pancing dari kawat baja dan pemberat terbuat dari timah. Pancing gulung dipasang pada bagian tepi perahu (1 perahu pada umumnya 1 orang dengan jumlah pancing 3 sampai dengan 8 buah). Tali pancing diulur sampai dengan ke dasar perairan antara 4 sampai dengan 10 m sedemikian rupa sehingga mata pancing dan umpan berada di atas dasar perairan. Umpan yang digunakan adalah cacing nipah, cacing tanah, atau cacing lambo, dan anak udang. Habitat tempat memancing pada perairan sungai bagian tepi yang berwarna kecoklatan sampai dengan kehitam-hitaman dengan kondisi banyak tumpukan kayu dan sampah organik dari limbah domestik rumah tangga.

\section{Rawai Udang (Long lines)}

Alat tangkap terdiri atas tali nylon multifilamen dengan panjang $\pm 525 \mathrm{~m}$, pada tali nylon diikatkan kawat atau paku yang berfungsi sebagai mata pancing dengan jarak $\pm 1,5 \mathrm{~m}$ sehingga sepanjang tali terdapat \pm 350 mata pancing. Setiap mata dikaitkan potongan kelapa ukuran 1,5 cm persegi. Untuk menangkap udang digunakan sauk (scoopnet). Alat bantu ini terbuat dari papan seperti dayung yang dihubungkan dengan pegangan berlapis karet dan dihubungkan pula dengan lingkaran kawat + jaring net yang berfungsi sebagai serok. Panjang alat $\pm 80 \mathrm{~cm}$, lebar $\pm 60 \mathrm{~cm}$, tinggi net $\pm 60 \mathrm{~cm}$, dan mesh size net $\pm 1 / 2$ inci. Tali nylon rawai dipasang sejajar garis pantai pada jarak \pm 5 sampai dengan $15 \mathrm{~m}$ dan ujung-ujung diikatkan pada tiang pancang bambu. Kedalaman tali nylon dari permukaan air \pm 70 sampai dengan $80 \mathrm{~cm}$. Rawai dipasang pada jam 6.00 sore, dibiarkan $\pm 0,5$ sampai dengan 1 jam dan dilakukan penangkapan setiap 10 menit disusur dengan alat tangkap bantu sauk. Sauk disusurkan bersamaan dengan mendayung perahu untuk memeriksa setiap mata pancing pada rawai. Bila terdapat udang pada mata pancing, udang diambil dengan sauk dan dimasukan ke dalam palka perahu. Habitat pemasangan rawai udang adalah di bagian tepi sungai yang banyak pepohonan dan di bagian hilir yang banyak tumbuhan bakau. Pemasangan alat dimulai dari waktu setelah magrib sampai dengan waktu subuh.

\section{Bubu udang (Traps)}

Bubu udang terbuat dari bilah bambu, berbentuk silinder dengan bagian belakang mengerucut. Bagian muka atau pintu tempat masuk udang berbentuk lingkaran berdiameter $\pm 30 \mathrm{~cm}$, panjang bubu berkisar 80 sampai dengan $120 \mathrm{~cm}$. Bagian dalam bubu dilengkapi 2 buah injab terbuat dari kawat, terpasang di bagian muka dan tengah. Bagian dalam bubu diberi umpan kelapa terletak di bagian belakang setelah injab ke-2. Agar bubu dapat terendam dalam air, di bagian dalam diberi pemberat berupa batu. Pemasangan alat dilakukan dengan cara setiap bubu dihubungkan tali dan diikatkan pada tali ris utama. Bubu terpasang pada bagian atas permukaan bagian dasar perairan. Bagian muka (pintu) bubu dipasang memotong arus. Bubu dipasang pada pagi atau sore hari dan diperiksa setiap 2 hari sekali. Habitat pemasangan bubu yaitu pada bagian pantai yang banyak terdapat muaramuara sungai dan dipasang menghadap air surut.

\section{Jala (Cast Net)}

Jala udang terbuat dari jaring net dengan mesh size 0,5" dari atas 1 sampai dengan 1,5" di bagian bawah. Alat ini berbentuk kerucut (melebar ke arah bawah) dengan panjang 3 sampai dengan 3,5 m, dilengkapi batu pemberat terbuat dari timah dan bagian atas diikatkan tali dengan panjang $\pm 5 \mathrm{~m}$. Jala dioperasikan dengan cara alat tersebut dilempar sedemikian rupa sehingga jala mengembang membentuk lingkaran. Jala digunakan pada habitat perairan sungai yang keadaan tidak begitu dalam di 
bagian tepi. Lama menangkap \pm 4 sampai dengan 5 jam dari jam 09.00 sampai dengan 14.00. Penangkapan dilakukan pada musim kemarau, di musim hujan juga ada penangkapan tetapi tidak seintensif pada waktu musim kemarau.

\section{Jaring (Gill Net)}

Jaring atau pukat yang dipakai untuk menangkap udang galah (Macrobrachium rosenbergii) sampai dengan tergolong pukat dasar (bottom gill net). Alat ini terdiri atas lembaran jaring dengan mesh size 2 sampai dengan 2,5 inci, batu pemberat, pelampung, tali ris atas, dan tali ris bawah. Jaring dipasang memotong arus sungai sehingga posisi hampir tegak lurus dengan garis pantai. Jaring dipasang pada berbagai posisi di perairan sungai (di bagian tepi, tengah, dan juga dekat muara). Jaring untuk menangkap udang dipasang di dasar perairan sehingga jaring dalam keadaan tenggelam dan badan jaring tegak vertikal menghadang arus sungai. Panjang jaring yang digunakan $\pm 60 \mathrm{~m}$ dan tinggi 3 sampai dengan $5 \mathrm{~m}$, serta mesh size 2,5 inci. Jaring dipasang selama \pm 5 sampai dengan 6 jam (ada yang dimulai dari pagi sampai dengan siang dan ada dari sore sampai dengan malam). Periksa hasil tangkapan antara 1 sampai dengan 2 jam sekali.

\section{Blad (Barrier trap)}

Blad termasuk jenis trap (perangkap) terdiri atas anyaman bambu berbentuk lembaran (tinggi 2,5 m dan lebar $3 \mathrm{~m}$ ) disebut empang. Lembaran bambu dipasang sambung-menyambung seperti pagar berbentuk hati (amor) dan berlapis 3 yang ukuran berbeda. Pada blad pertama ukuran mulut $30 \mathrm{~cm}$, ke-2 $20 \mathrm{~cm}$ dan ke-3 $10 \mathrm{~cm}$. Ukuran lebar dan panjang blad pertama $4 \times 4 \mathrm{~m}^{2}$, ke-2 1,5×1,5 m², dan yang ke$31 \times 1 \mathrm{~m}^{2}$. Di bagian ujung pada blad ke-3 dipasang tonggak kayu agar posisi tidak berubah bila diterpa gelombang atau arus air sungai. Blad dipasang pada sungai bagian tepi berjarak $\pm 10 \mathrm{~m}$, tegak lurus dengan garis pantai dan mulut atau tempat masuk udang menghadap pantai. Blad dipasang di perairan sungai yang banyak ditumbuhi oleh tumbuh-tumbuhan dari famili Graminae dan tumbuhan eceng gondok. Habitat tersebut pada umumnya landai dan pengaruh pasang surut kuat terhadap blad terpasang. Prinsip penangkapan ikan atau udang dengan blad adalah dengan cara menggiring atau mengarahkan ikan atau udang agar ke arah mulut sehingga ikan atau udang yang masuk tidak dapat ke luar lagi. Ikan atau udang akan terus bergerak ke arah blad terkecil sampai dengan akhirnya terkumpul didekat ujung blad terkecil tersebut tepat pada posisi tombak yang diikatkan pada blad terakhir. Untuk selanjutnya, ikan atau udang yang terkurung di blad terakhir tersebut diambil atau dipanen.

\section{Rompong (Fish Aggregating Device)}

Rompong atau rumpon merupakan alat tangkap ikan dan udang yang banyak terdapat di daerah bagian hilar, khususnya di daerah Sungai Kakap, Kabupaten Pontianak. Bahan dan alat yang digunakan adalah ranting kayu, tonggak, empang, dan kayu balok. Di Sungai Kakap, nelayan menggunakan kayu balok berdiameter $10 \mathrm{~cm}$, sedangkan di Jungkat menggunakan ranting kayu. Diameter lingkaran rompong antara 3 sampai dengan $4 \mathrm{~m}$. Alat bantu untuk menangkap udang digunakan serok berdiameter $50 \mathrm{~cm}$ dan panjang $100 \mathrm{~cm}$. Rompong dipasang pada tanah beting yaitu tanah yang menjorok ke arah air dan tidak dalam $( \pm 1 \mathrm{~m})$. Prinsip penangkapan udang dengan rompong adalah bagaimana membuat udang tertarik untuk berlindung atau berkumpul di tempat yang ada ranting atau balok kayu yang telah dipasang. Ranting yang terpasang dibiarkan sampai dengan 2 minggu, sedangkan balok kalau kayu baru dibiarkan dahulu terendam air \pm 10 hari sampai dengan keadaan berlumut. Selanjutnya, tumpukan balok atau ranting yang berfungsi sebagai rumpon dikurung dengan empang bambu dikerjakan berkelompok, pada umumnya 3 sampai dengan 4 orang dengan cepat agar udang tidak lari. Setelah terkurung dan dipastikan tidak ada lagi tempat bagi udang untuk meloloskan diri, maka ranting dan balok dikeluarkan dari dalam empang. Kemudian dilakukan pengambilan atau panen. Untuk mempermudah panen, lingkaran empang sedikit demi sedikit diperkecil radius. Kalau hasil panen banyak, maka tempat tersebut digunakan lagi dengan bahan yang ada, tetapi kalau hasil sedikit tempat tersebut ditinggal dan mencari tempat lain dengan bahan yang sudah ada.

\section{Pukat Rantau (Fish Aggregating Device)}

Pukat rantau menggunakan bahan jaring dengan mesh size kecil atau rapat $( \pm 1 \mathrm{~cm})$. Bahan dan alat yang digunakan terdiri dari patok kayu, lembar jaring yang dilengkapi tali ris atas dan bawah serta batu pemberat, di samping itu untuk menarik udang atau ikan ke dalam lahan tangkap, maka diberi beberapa dahan, ranting dan dedaunan sebagai rumpon. Ukuran panjang jaring berkisar 200 sampai dengan $300 \mathrm{~m}$ dan terpasang dalam bentuk 1/2 lingkaran. Mekanisme penangkapan ikan atau udang oleh alat pukat rantau ada hubungan dengan pasang surut air laut, dengan demikian alat tangkap ini banyak dijumpai pada perairan sungai bagian hilir. Habitat yang dipilih 
adalah perairan bagian tepi sungai yang banyak terdapat tumbuhan air dan tebing landai (saat air pasang tergenang dan saat air surut sedimen dasar kelihatan). Setelah lokasi sesuai, dipasang patokpatok kayu sebagai tempat melekatkan lembar jaring. Patok dan lembar jaring dipasang 1/2 lingkaran mengikuti garis pantai. Cara kerja alat adalah pada waktu air surut, jaring diangkat atau digantung atau diletakkan di dasar untuk memberi jalan pada ikan dan udang menuju ke arah rumpon bersamaan dengan datang air pasang, pada jam \pm 12 malam di mana terjadi pasang tertinggi, jaring yang digantung diturunkan atau yang terletak di dasar diangkat sehingga lahan tangkap yang di dalam terdapat rumpon tertutup oleh jaring dan tidak ada celah sedikitpun bagi ikan atau udang untuk meloloskan diri. Saat air menjelang surut dan terjadi surut terendah pada pagi hari, maka mulai dilakukan pengambilan ikan (panen).

\section{Stroom (Electrical Fishing)}

Alat tangkap udang atau ikan dengan menggunakan stroom (aliran listrik) termasuk alat tangkap yang dilarang sehingga untuk menjumpai nelayan yang menggunakan alat tangkap ini tergolong sulit. Peralatan terdiri atas 2 buah baterai DC (a 12 volt) $=24$ volt. Alat bantu adalah stik kayu dengan panjang 2 sampai dengan $4 \mathrm{~m}$ yang ujung dilengkapi serok (scoope net) dan dilingkari kawat yang sudah tersambung dengan arus listrik berasal dari baterai accu. Sebagai pengamanan alat tangkap dilengkapi dengan tombol hidup mati. Mekanisme menangkap udang atau ikan dengan alat listrik yaitu serok yang mengandung aliran listrik dimasukan dalam air (pada bagian tepi sungai yang banyak tumbuhan air dan air tidak begitu dalam), kebanyakan dilakukan pada malam hari untuk menghindari petugas. Ikan atau udang yang tertangkap dengan aliran listrik meliputi semua ukuran karena alat tangkap dengan arus listrik merupakan alat tangkap non selektif.

\section{Hasil Tangkapan Udang Galah (Macrobrachium rosenbergii)}

Hasil tangkapan udang galah (Macrobrachium rosenbergii) per upaya (catch per unit of effort) dari setiap jenis alat tangkap di masing-masing wilayah pengamatan dari survei pertama sampai dengan survei ke-4 dapat dilihat pada Tabel 2 sampai dengan Tabel 5. Dari data yang diperoleh, alat tangkap bubu (bubu udang) merupakan alat tangkap yang tidak produktif dalam hal menangkap udang galah (Macrobrachium rosenbergii). Selama survei dari bulan Juni sampai dengan Desember 2005, hasil tangkapan udang per satuan upaya (catch per unit of effort) berkisar antara 1,39 g per bubu per jam (bulan Oktober) sampai dengan 6,25 g per bubu per jam (bulan Juni). Alat tangkap yang tergolong produktif menangkap udang galah adalah jala berkisar antara 196,39 g per jala per jam (bulan Oktober) sampai dengan 416,67 g per jala per jam (bulan Agustus). Alat tangkap lain yang juga tergolong produktif urutan 2 dan 3 adalah pukat dan rawai masing-masing 166,67 g per unit pukat per jam dan 149,55 g per unit rawai per jam. Pada survei ke-2, ditemukan pula nelayan yang menggunakan alat tangkap stroom dengan hasil tangkapan sekitar 337,5 g udang per unit alat stroom per jam operasi tangkap.

Udang galah (Macrobrachium rosenbergii) tergolong hewan akuatik yang dapat beruaya jauh. Fase larva sampai dengan juvenil, udang galah (Macrobrachium rosenbergii) lebih banyak tinggal di perairan sungai bagian hilir pada muara-muara yang dipengaruhi oleh air laut. Dalam proses menuju dewasa, udang galah (Macrobrachium rosenbergii) melakukan migrasi ke arah hulu sampai dengan dewasa. Proses pembuahan sel telur oleh udang jantan pada umumnya terjadi di wilayah tengah dan hulu, dan selanjutnya udang akan bermigrasi kembali ke arah hilir mencari habitat perairan yang mengandung kadar garam untuk melakukan penetasan telur.

Tabel 2. Hasil tangkapan per upaya setiap jenis alat tangkap pada survei ke-1(bulan Juni-2005) Table 2. Catch per unit of effort of each fishing gear in the $1^{\text {st }}$ survey (June 2005)

\begin{tabular}{|c|c|c|c|c|c|c|}
\hline \multirow[t]{2}{*}{ No. } & \multirow{2}{*}{$\begin{array}{c}\text { Jenis alat } \\
\text { tangkap/Catch } \\
\text { nshing }\end{array}$} & \multicolumn{4}{|c|}{$\begin{array}{l}\text { Hasil tangkapan per satuan upaya/Catch per unit of effort } \\
\text { (g per unit alat per jam) }\end{array}$} & \multirow{2}{*}{$\begin{array}{c}\text { Nilai rata-ratai } \\
\text { Mean }\end{array}$} \\
\hline & & $\mathbf{A}$ & B & $\mathrm{C}$ & D & \\
\hline 1. & Pancing & 12,27 & 53,61 & 68,75 & 25,00 & 39,91 \\
\hline 2. & Jala & 55,56 & 204,2 & 171,67 & 228,57 & 165,00 \\
\hline 3. & Beladiempang & 145,83 & - & - & - & - \\
\hline 4. & Bubu udang & 6,25 & - & - & - & - \\
\hline 5. & Jaringipukat & - & 40,00 & - & - & - \\
\hline
\end{tabular}

Keterangan/Remarks: A = perairan Sungai Kapuas dalam Kabupaten Pontianak; B = perairan Sungai Kapuas dalam Kota Pontianak; C $=$ perairan Sungai Kapuas dalam Kabupaten Sanggau; D = perairan Sungai Kapuas dalam Kabupaten Sintang 
Tabel 3. Hasil tangkapan per upaya setiap jenis alat tangkap survei ke-2 (bulan Agustus 2005)

Table 3.

Catch per unit of effort of each fishing gear in the $2^{\text {nd }}$ survey (August 2005)

\begin{tabular}{|c|c|c|c|c|c|c|}
\hline \multirow[t]{2}{*}{ No. } & \multirow{2}{*}{$\begin{array}{c}\text { Jenis alat } \\
\text { tangkap/Catch } \\
\text { fishing }\end{array}$} & \multicolumn{4}{|c|}{$\begin{array}{c}\text { Hasil tangkapan per satuan upaya/Catch per unit of effort } \\
\text { (g per unit alat per jam) }\end{array}$} & \multirow{2}{*}{$\begin{array}{c}\text { Nilai rata-rata' } \\
\text { Mean }\end{array}$} \\
\hline & & $\mathbf{A}$ & B & C & D & \\
\hline 1. & Jaringipukat & 150,00 & - & - & 62,50 & - \\
\hline 2. & Jala & 195,40 & 108,41 & 141,25 & 416,67 & 215,43 \\
\hline 3. & Rompong & 3,87 & - & - & - & - \\
\hline 4. & Bubu udang & 2,08 & 2,08 & 5,00 & - & - \\
\hline 5. & Pukat rantau & 166,67 & - & - & - & - \\
\hline 6. & Pancing & 14,59 & 64,65 & 42,21 & 41,67 & 40,78 \\
\hline 7. & Rawai udang & 149,55 & - & - & - & - \\
\hline 8. & Stroom accu & - & 337,50 & - & - & - \\
\hline
\end{tabular}

Intensitas penangkapan udang galah (Macrobrachium rosenbergii) di Sungai Kapuas terlihat dominan di perairan bagian hilir dalam wilayah Kabupaten dan Kota Pontianak. Sembilan jenis alat tangkap yang digunakan nelayan terdapat pada wilayah pengamatan bagian hilir Sungai Kapuas dalam Kabupaten dan Kota Pontianak. Di wilayah pengamatan di Kabupaten Sanggau dan Sintang, alat tangkap udang yang sering digunakan nelayan adalah pancing, jala, rawai, bubu, dan jaring atau pukat. Di perairan bagian hilir, khususnya perairan dalam wilayah Kecamatan Sungai Kakap, Kabupaten Pontianak, alat tangkap yang menjadi andalan nelayan untuk menangkap udang galah (Macrobrachium rosenbergii) adalah rompong dan jala. Berdasarkan pada informasi dari nelayan terdapat lebih kurang 300 rompong di perairan Muara Sungai Kakap. Satu kelompok nelayan yang terdiri atas 2 sampai dengan 3 kepala keluarga dapat memiliki 10 sampai dengan 15 buah rompong. Pengambilan hasil tangkapan (panen) adalah dengan cara digilir 1 demi 1 setiap hari. Setiap rompong yang sama akan mendapat giliran dipanen setiap 10 hari sekali. Hal ini, terjadi bila kelompok nelayan mempunyai 10 buah rompong. Kemampuan 1 kelompok nelayan dalam mengambil hasil panen udang berkisar dari 1 sampai dengan 2 rompong per hari (rata-rata 1 rompong per hari) karena ada pengaruh air pasang. Alat tangkap ke-2 yang juga menjadi andalan setelah rompong adalah jala. Penangkapan udang galah (Macrobrachium rosenbergii) menggunakan jala sering dilakukan pada malam dan siang hari, tergantung pada musim, keadaan cuaca dan kondisi air. Pada musim bulan gelap, nelayan menangkap udang pada malam hari antara jam 20.00 sampai dengan 02.00 malam, sedangkan pada musim bulan terang, nelayan menangkap udang pada siang hari yaitu selepas subuh sampai dengan jam 12 siang. Di perairan Sungai Kapuas bagian hilir (Daerah Jungkat), alat tangkap yang menjadi andalan adalah pancing, jala, dan blad atau empang.

Tabel $4 \quad$ Hasil tangkapan per upaya setiap jenis alat tangkap survei ke-3 (bulan Oktober 2005) Table 4. Catch per unit of effort of each fishing gear in the $3^{\text {rd }}$ survey (October 2005)

\begin{tabular}{|c|c|c|c|c|c|c|}
\hline \multirow[t]{2}{*}{ No. } & \multirow{2}{*}{$\begin{array}{c}\text { Jenis alat } \\
\text { tangkapiCatch } \\
\text { fishing }\end{array}$} & \multicolumn{4}{|c|}{$\begin{array}{c}\text { Hasil tangkapan per satuan upaya/Catch per unit of effort } \\
\text { (g per unit alat per jam) }\end{array}$} & \multirow{2}{*}{$\begin{array}{c}\text { Nilai rata-ratai } \\
\text { Mean }\end{array}$} \\
\hline & & A & B & $\mathrm{C}$ & D & \\
\hline 1. & Jala & 136,46 & 196,39 & - & - & - \\
\hline 2. & Pancing & 21,84 & 22,05 & 19,95 & 46,42 & 27,57 \\
\hline 3. & Rawai udang & 131,94 & - & - & 118,18 & - \\
\hline 4. & Bubu udang & 1,39 & - & - & - & - \\
\hline 5. & Rompong & 11,91 & - & - & - & - \\
\hline 6. & Jaringipukat & - & - & - & 97,92 & - \\
\hline
\end{tabular}

Keterangan/Remarks: A = perairan Sungai Kapuas dalam Kabupaten Pontianak; B = perairan Sungai Kapuas dalam Kota Pontianak; $\mathrm{C}=$ perairan Sungai Kapuas dalam Kabupaten Sanggau;D = perairan Sungai Kapuas dalam Kabupaten Sintang 
Tabel 5. Hasil tangkapan per upaya setiap jenis alat tangkap survei ke-4 (bulan Desember 2005) Table 5. $\quad$ Catch per unit of effort of each fishing gear in the $4^{\text {th }}$ survey (December 2005)

\begin{tabular}{|c|c|c|c|c|c|c|}
\hline \multirow[t]{2}{*}{ No. } & \multirow{2}{*}{$\begin{array}{c}\text { Jenis alat } \\
\text { tangkapiCatch } \\
\text { fishing }\end{array}$} & \multicolumn{4}{|c|}{$\begin{array}{c}\text { Hasil tangkapan per satuan upaya/Catch per unit of effort } \\
\text { (g per unit alat per jam) }\end{array}$} & \multirow{2}{*}{$\begin{array}{c}\text { Nilai rata-ratai } \\
\text { Mean }\end{array}$} \\
\hline & & $\mathbf{A}$ & B & C & D & \\
\hline 1. & Pancing & 16,16 & 12,17 & 25,72 & 29,59 & 20,91 \\
\hline 2. & Jala & 130,24 & 366,67 & 161,98 & 250,00 & 227,22 \\
\hline 3. & Rawai udang & 104,55 & - & - & 109,09 & - \\
\hline 4. & Blad & 100 & - & - & - & - \\
\hline 5. & Rompong & 11,25 & - & - & - & - \\
\hline 6. & Bubu udang & - & - & 5,42 & - & - \\
\hline
\end{tabular}

Hasil tangkapan udang di wilayah pengamatan Kabupaten Sanggau dan Sintang didominasi oleh ukuran yang besar dan alat tangkap yang banyak digunakan adalah pancing dan jala. Udang galah (Macrobrachium rosenbergii) berukuran 9,38 sampai dengan $16,5 \mathrm{~cm}$ (dalam wilayah Kabupaten Pontianak) merupakan ukuran yang paling sering tertangkap. Berdasarkan pada kriteria yang dikatakan Utomo et al. (2002) udang galah (Macrobrachium rosenbergii) yang tertangkap di bagian hilir Sungai Kapuas mempunyai ukuran kecil $(<12 \mathrm{~cm})$ sampai dengan berukuran besar $(>15 \mathrm{~cm})$. Untuk wilayah pengamatan dalam Kabupaten Sintang, ukuran udang galah (Macrobrachium rosenbergii) yang sering tertangkap oleh nelayan berkisar antara 13,20 sampai dengan $25,99 \mathrm{~cm}$, ukuran ini merupakan ukuran sedang sampai dengan besar. Alat tangkap rompong di Sungai Kakap menggunakan balok sebagai rumpon untuk memikat udang agar berkumpul tetapi di Muara Jungkat menggunakan ranting dan cabang-cabang kayu. Alat tangkap blad atau empang di perairan dekat Muara Jungkat, sistem memanen udang adalah setiap hari pada waktu pagi hari. Alat tangkap ini terpasang terus setiap hari dan bila dirasakan pada lokasi tersebut hasil panen udang tidak memuaskan lagi, nelayan akan mencari lokasi lain, sedangkan lokasi lama yang ditinggalkan akan diulangi kembali dalam waktu $1 / 2$ sampai dengan 1 bulan berikut.

Alat tangkap pancing yang juga banyak digunakan nelayan, waktu penangkapan bervariasi antara pagisiang, siang-sore, dan ada juga yang memancing di malam hari. Informasi dari seorang nelayan, mengatakan bahwa waktu yang bagus untuk menangkap udang galah (Macrobrachium rosenbergii) dengan alat tangkap pancing adalah pada saat air kandak. Air kandak adalah istilah nelayan yaitu suatu keadaan, di mana air sungai pada waktu-waktu tertentu arus air tidak terlalu deras dan pasang tidak terlalu tinggi. Di samping itu, kondisi air sungai yang keruh dan berwarna coklat ditambah banyak tumpukan kayu-kayu atau ranting dan limbah domestik rumah tangga, berdasarkan pada pengalaman nelayan merupakan habitat perairan yang cocok dan sangat disenangi oleh udang galah (Macrobrachium rosenbergii).

\section{Distribusi Ukuran Udang Galah (Macrobrachium rosenbergii)}

Distribusi ukuran udang galah (Macrobrachium rosenbergii) yang tertangkap di masing-masing wilayah dan waktu pengamatan (distribusi spasial dan distribusi temporal) tertera pada Tabel 6 dan 7. Udang galah (Macrobrachium rosenbergii) yang tertangkap berdasarkan pada waktu (distribusi temporal) dan tempat (distribusi spasial) mempunyai ukuran yang berbeda. Ukuran panjang total udang galah (Macrobrachium rosenbergii) terkecil $6,0 \mathrm{~cm}$ dari survei ke-2 (bulan Agustus 2005) di wilayah Kabupaten Pontianak, ukuran tertinggi $30,7 \mathrm{~cm}$ dari survei ke-1 (bulan Juni 2005) dalam wilayah Kabupaten Sanggau. Ukuran rata-rata terkecil $11,41 \mathrm{~cm}$ dari survei ke-2 (bulan Agustus 2005) dalam wilayah Kabupaten Pontianak, ukuran rata-rata tertinggi diperoleh pada survei ke-1 (bulan Juni 2005) dalam wilayah pengamatan Kabupaten Sintang 21,59 cm. Ukuran yang banyak tertangkap (nilai modus) terkecil $=9,38$ $\mathrm{cm}$ dari survei ke-2 (bulan Agustus 2005) dalam wilayah Kabupaten Pontianak, nilai modus tertinggi $=25,99 \mathrm{~cm}$ dari survei ke-1 (bulan Juni 2005) wilayah Kabupaten Sintang. Dilihat dari satuan bobot, ukuran terkecil 2,7 g dari survei ke-2 (bulan Agustus 2005) wilayah pengamatan Kabupaten Pontianak. Tertinggi $=390 \mathrm{~g}$ dari survei ke-1 (bulan Juni 2005 wilayah Kabupaten Pontianak). Bobot rata-rata terkecil $=$ 18,23 g diperoleh pada survei ke-2 (bulan Agustus 2005 di Kabupaten Pontianak), bobot rata-rata tertinggi 132,42 g dari survei ke-1 (bulan Juni 2005) dalam wilayah Kabupaten Sintang. Nilai modus terkecil 17,73 g dari survei ke-2 (bulan Agustus 2005) dalam wilayah Kabupaten Pontianak. Nilai modus tertinggi 
100,57 g pada survei ke-2 dalam wilayah pengamatan Kabupaten Sintang.

Pada Tabel 7, distribusi ukuran bobot udang galah (Macrobrachium rosenbergii) yang sering tertangkap (nilai modus) dari 4 kali survei bervariasi antara 17,73 sampai dengan $40 \mathrm{~g}$ (Kabupaten Pontianak), antara 19,31 sampai dengan 47,01 g (Kota Pontianak), antara 17,79 sampai dengan 45, $35 \mathrm{~g}$ (Kabupaten Sanggau) dan antara 25,08 sampai dengan 85,52 g (Kabupaten Sintang). Udang yang tertangkap pada survei ke-2 (bulan Agustus 2005) bobot tubuh tergolong paling kecil dibandingkan pada survei ke-1, 3, dan 4. Di Kalimantan Barat, nelayan mengelompokkan ukuran bobot udang galah (Macrobrachium rosenbergii) menjadi 3 bagian yaitu ukuran udang galah (Macrobrachium rosenbergii) dengan bobot tubuh di atas $100 \mathrm{~g}$ dikelompokkan dalam golongan A, ukuran bobot 30 sampai dengan $100 \mathrm{~g}$ dikelompokkan dalam golongan $B$ dan ukuran kurang dari $30 \mathrm{~g}$ dikelompokkan dalam golongan C. Golongan A dibagi lagi menjadi 3 bagian yaitu A super berukuran di atas $200 \mathrm{~g}$, A1 ukuran antara 150 sampai dengan $200 \mathrm{~g}$, dan A2 yaitu ukuran antara 100 sampai dengan 150 g. Golongan $C$ dibagi menjadi 2 bagian yaitu Ck (C kecil) yaitu ukuran 10 sampai dengan $30 \mathrm{~g}$ dan $\mathrm{Ch}$ (C halus) yaitu ukuran kurang dari $10 \mathrm{~g}$. Dari ukuranukuran tersebut, dapat disimpulkan bahwa udang galah (Macrobrachium rosenbergii) yang banyak tertangkap oleh nelayan di perairan Sungai Kapuas termasuk dalam golongan $B$ dan $C$, sedangkan golongan A meskipun dijumpai pada pasar-pasar ikan, jumlah tergolong sedikit.

\section{Aspek Reproduksi Udang Galah (Macrobrachium rosenbergii)}

Di perairan Sungai Kapuas bagian hilir yang mencakup wilayah Kabupaten dan Kota Pontianak terdapat induk-induk udang galah (Macrobrachium rosenbergii) yang sudah dibuahi pada berbagai tingkat kematangan gonad yaitu dari tingkat kematangan gonad I (gonad berwarna kuning), tingkat kematangan gonad II (jingga), tingkat kematangan gonad III (coklat), dan tingkat kematangan gonad IV (abu-abu). Dalam wilayah pengamatan Kabupaten Sanggau dan Sintang jarang ditemukan tingkat kematangan gonad udang galah tingkat kematangan gonad pada tingkat II, III, dan IV, sedangkan untuk tingkat kematangan gonad I, frekuensi didapatkan tidak sebanyak pada wilayah pengamatan di Kabupaten dan Kota Pontianak. Ukuran udang galah tingkat kematangan gonad betina terkecil yang mencapai tingkat kematangan gonad IV terjadi pada panjang total $13 \mathrm{~cm}$ dan bobot tubuh
$18,4 \mathrm{~g}$, bobot gonad 2,23 g dengan fekunditas 7.058 butir (Tabel 8). Ukuran tertinggi $18,2 \mathrm{~cm}$ dengan bobot tubuh $55 \mathrm{~g}$, tingkat kematangan gonad III dengan bobot gonad 4,14 g dan fekunditas 49.584 butir. Fekunditas udang galah (Macrobrachium rosenbergii) bervariasi antara 7.058 sampai dengan 57.887 butir. Diameter telur pada berbagai tingkat kematangan gonad (Tabel 9) frekuensi yang terbanyak terjadi pada kisaran diameter 0,30 sampai dengan 0,349 $\mathrm{mm}$ baik pada tingkat kematangan gonad I, tingkat kematangan gonad II, tingkat kematangan gonad III, maupun tingkat kematangan gonad IV, namun diameter telur dengan ukuran nilai tengah antara 0,5745 sampai dengan $0,7745 \mathrm{~mm}$ hanya ada pada induk udang galah (Macrobrachium rosenbergii) dengan tingkat kematangan gonad IV yang dicirikan warna telur abuabu.

\section{Kualitas Air}

Pengukuran parameter kualitas air dilakukan pada lokasi di mana ditemukan nelayan sedang melakukan aktivitas penangkapan udang galah (Macrobrachium rosenbergii) di perairan Sungai Kapuas. Tabel 10 merupakan hasil pengukuran kualitas air pada setiap survei di setiap wilayah pengamatan. Dari 4 kali survei, suhu air terendah $26,5^{\circ} \mathrm{C}$ dan yang tertinggi $31^{\circ} \mathrm{C}$. Nilai kecerahan berkisar antara 20 sampai dengan $60 \mathrm{~cm}$, warna air berkisar dari coklat, abu-abu, sampai dengan hitam, namun secara keseluruhan, warna air Sungai Kapuas adalah coklat. pH air daerah aliran Sungai Kapuas berkisar antara 5,0 sampai dengan 7,5 , nilai pH terendah $(5,0)$ terukur pada lokasi muara Sungai Landak dalam wilayah pengamatan Kota Pontianak, sedangkan yang tertinggi $(\mathrm{pH}=7,5)$ terukur pada lokasi di Muara Sungai Kakap dalam wilayah pengamatan Kabupaten Pontianak. Kadar oksigen terlarut bervariasi dari 4,39 sampai dengan 6,44 mg per I, sedangkan kadar $\mathrm{CO}_{2}$ bebas antara 6,6 sampai dengan 11,0 mg per I.

Hasil pengukuran beberapa parameter kualitas air Sungai Kapuas dari hulu (Kabupaten Sanggau dan Sintang) sampai dengan ke bagian hilir (Kabupaten dan Kota Pontianak) tidak menunjukkan perbedaan yang besar antara satu wilayah dengan wilayah pengamatan yang lain. Nilai-nilai yang terukur pada parameter suhu, kecerahan, $\mathrm{pH}$, kadar oksigen $\left(\mathrm{O}_{2}\right)$ terlarut, dan karbondioksida $\left(\mathrm{CO}_{2}\right)$ bebas selama melakukan penelitian ( 4 kali survei) dalam batas-batas yang layak untuk mendukung kehidupan organisme perairan termasuk ikan dan udang (APHA, 1988; Boyd, 1979; NTAC, 1968). 

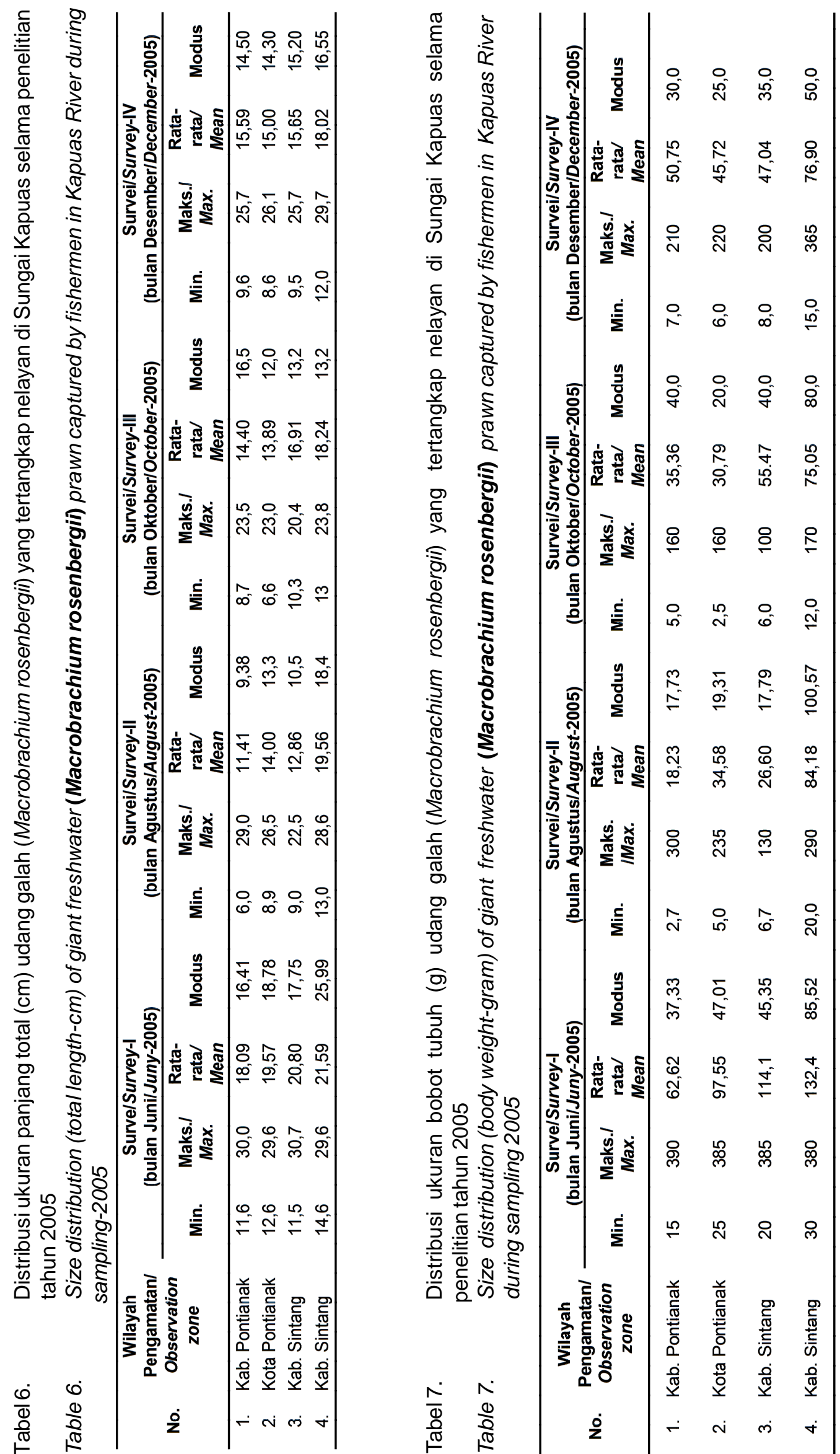
Tabel 8. Data panjang bobot, tingkat kematangan gonad, warna, bobot gonad, dan fekunditas udang galah (Macrobrachium rosenbergii) di perairan Sungai Kapuas dalam wilayah Kabupaten dan Kota Pontianak

Table 8. Data of length eight, gonad maturity stage, colour, and weight of gonad and fecundity of giant freshwater (Macrobrachium rosenbergii) prawn in Kapuas River in District and City of Pontianak

\begin{tabular}{ccccccc}
\hline No. & $\begin{array}{c}\text { Panjang } \\
\text { Total/Total } \\
\text { length } \mathbf{( c m})\end{array}$ & $\begin{array}{c}\text { Bobot/ } \\
\text { Weight } \\
\text { (g) }\end{array}$ & $\begin{array}{c}\text { TKG/ } \\
\text { GMS }\end{array}$ & $\begin{array}{c}\text { Warna } \\
\text { Gonad/ } \\
\text { Gonad color }\end{array}$ & $\begin{array}{c}\text { Bobot gonad/ } \\
\text { Gonad weight } \\
\text { (g) }\end{array}$ & $\begin{array}{c}\text { Fekunditas/ } \\
\text { Fecundity } \\
\text { (butir) }\end{array}$ \\
\hline 1. & 15,1 & 30 & III & Coklat & 1,99 & 37.602 \\
2. & 18,2 & 55 & III & Coklat & 4,14 & 49.584 \\
3. & 15,5 & 35 & II & Jingga & 2,93 & 25.868 \\
4. & 16,8 & 45 & II & Jingga & 1,80 & 27.480 \\
5. & 14,1 & 20 & III & Coklat & 1,55 & 11.563 \\
6. & 17,3 & 50 & IV & Abu-abu & 3,03 & 24.066 \\
7. & 16,7 & 45 & II & Jingga & 1,14 & 16.886 \\
8. & 17,0 & 45 & IV & Abu-abu & 0,96 & 17.424 \\
9. & 15,5 & 32,0 & I & Kuning & 3,45 & 24.649 \\
10. & 16,5 & 42,1 & II & Jingga & 5,14 & 39.835 \\
11. & 15,5 & 37,4 & II & Jingga & 3,03 & 17.637 \\
12. & 15,0 & 39,9 & II/III & Jingga & 3,96 & 27.816 \\
13. & 16,0 & 53,1 & III & Coklat & 4,87 & 57.887 \\
14. & 15,5 & 34,3 & II & Jingga & 2,16 & 17.934 \\
15. & 17,5 & 52,6 & III & Coklat & 5,74 & 26.215 \\
16. & 14,5 & 36,7 & IV & Abu-abu & 3,30 & 13.800 \\
17. & 13,0 & 18,4 & IV & Abu-abu & 2,23 & 7.058 \\
18. & 15,3 & 33,4 & IV & Abu-abu & 2,53 & 20.971 \\
\hline
\end{tabular}

Tabel 9. Distribusi diameter telur udang galah (Macrobrachium rosenbergii) pada berbagai tingkat kematangan gonad

Table 9. Distribution of diameter of the eggs of giant freshwater (Macrobrachium rosenbergii) prawn at several gonad maturity stages

\begin{tabular}{|c|c|c|c|c|c|c|}
\hline \multirow{3}{*}{ No. } & \multirow{3}{*}{$\begin{array}{l}\text { Diameter telur/ } \\
\text { Egg diameter } \\
(\mathrm{mm})\end{array}$} & \multirow{3}{*}{$\begin{array}{l}\text { Nilai tengah/ } \\
\text { Mean } \\
(\mathrm{mm})\end{array}$} & \multicolumn{4}{|c|}{$\begin{array}{l}\text { Frekuensi (\%) diameter telur pada/ } \\
\text { Frequency of egg diameter of }\end{array}$} \\
\hline & & & TKG/GSMI & TKG/GSM II & TKG/GSM III & TKG/GSM IV \\
\hline & & & Kuning & Jingga & Coklat & Abu-abu \\
\hline 01 & $0,25-0,299$ & 0,27 & 2 & 33,5 & 44 & 10,5 \\
\hline 02 & $0,30-0,349$ & 0,32 & 70 & 36 & 47 & 33,5 \\
\hline 03 & $0,35-0,399$ & 0,37 & 22 & 20 & 8 & 16 \\
\hline 04 & $0,40-0,449$ & 0,42 & 2 & 7,5 & 1 & 8,5 \\
\hline 05 & $0,45-0,499$ & 0,47 & 0 & 0 & & 0 \\
\hline 06 & $0,50-0,549$ & 0,52 & 4 & 3 & & 13,5 \\
\hline 07 & $0,55-0,599$ & 0,57 & & & & 4 \\
\hline 08 & $0,60-0,649$ & 0,62 & & & & 11,5 \\
\hline 09 & $0,65-0,699$ & 0,67 & & & & 0 \\
\hline 10 & $0,70-0,749$ & 0,72 & & & & 0 \\
\hline 11 & $0,75-0,799$ & 0,77 & & & & 2,5 \\
\hline ** & Jumlah/Total & - & 100 & 100 & 100 & 100 \\
\hline ** & $\begin{array}{l}\text { Rata-rata diameter telur } \\
(\mathrm{mm})\end{array}$ & - & 0,35 & 0,33 & 0,31 & 0,42 \\
\hline ** & $\begin{array}{l}\text { Modus diameter telur } \\
\text { (mm) }\end{array}$ & - & 0,33 & 0,31 & 0,30 & 0,33 \\
\hline
\end{tabular}


Tabel 10. Nilai parameter kualitas air pada habitat penangkapan udang galah (Macrobrachium rosenbergii) di daerah aliran Sungai Kapuas, Kalimantan Barat selama penelitian

Table 10. The value of water quality parameters in the habitat of giant freshwater (Macrobrachium rosenbergii) prawn captured by fishermen in Kapuas River during the study

\begin{tabular}{|c|c|c|c|c|c|c|}
\hline \multirow{3}{*}{$\begin{array}{c}\text { Wilayah } \\
\text { pengamatan/ } \\
\text { observation zone }\end{array}$} & \multicolumn{6}{|c|}{ Parameter kualitas air yang diukur/Parameter of water quality } \\
\hline & $\begin{array}{c}\text { Suhu } \\
\text { Iermometer } \\
\left({ }^{\circ} \mathrm{C}\right)\end{array}$ & $\begin{array}{l}\text { Kecerahani } \\
\text { Iransparancy } \\
\text { (cm) }\end{array}$ & $\begin{array}{l}\text { Warna air' } \\
\text { Water color }\end{array}$ & $\begin{array}{c}\mathrm{pH} \text { air } / \\
p H \\
\text { (unit) }\end{array}$ & $\begin{array}{c}\text { Oksigen } \\
\text { oxygen } \\
\text { (ppm) }\end{array}$ & $\begin{array}{c}\text { CO2 bebas } \\
\text { Free } \mathrm{CO} 2 \\
\text { (ppm) }\end{array}$ \\
\hline & \multicolumn{6}{|c|}{ Survei ke-1 (bulan Mei sampai dengan Juni 2005) } \\
\hline $\begin{array}{l}\text { Kabupaten } \\
\text { Pontianak }\end{array}$ & $27,5-28,0$ & $30-33$ & Coklat & $6,0-6,3$ & $4,39-5,81$ & $6,6-8,8$ \\
\hline Kota Pontianak & $26,5-27,5$ & $23-35$ & $\begin{array}{l}\text { Coklat, } \\
\text { abu-abu }\end{array}$ & $5,0-6,3$ & $4,77-5,68$ & $6,6-8,8$ \\
\hline $\begin{array}{l}\text { Kabupaten } \\
\text { Sanggau }\end{array}$ & $27,0-27,5$ & $30-33$ & Abu-abu, hijau & 6,3 & $5,81-5,94$ & $6,6-11,0$ \\
\hline Kabupaten Sintang & $27,5-28,0$ & $25-30$ & Coklat & $5,8-6,5$ & $5,81-5,94$ & $6,6-11,0$ \\
\hline \multicolumn{7}{|c|}{ Survei ke-2 (bulan Agustus 2005) } \\
\hline $\begin{array}{l}\text { Kabupaten } \\
\text { Pontianak }\end{array}$ & $28,0-30,0$ & $25-35$ & Coklat, hitam & $6,0-6,3$ & $4,52-5,42$ & $6,6-11,0$ \\
\hline Kota Pontianak & $27,5-29,0$ & 30 & $\begin{array}{l}\text { Coklat, } \\
\text { abu-abu }\end{array}$ & $5,0-6,3$ & $4,90-5,81$ & $6,6-8,8$ \\
\hline $\begin{array}{l}\text { Kabupaten } \\
\text { Sanggau }\end{array}$ & $26,5-29,0$ & $25-30$ & Coklat & $6,0-6,3$ & $5,16-5,68$ & $8,8-11,0$ \\
\hline Kabupaten Sintang & $27,0-27,5$ & 20 & Coklat & $6,0-6,2$ & $5,36-5,55$ & $6,6-8,8$ \\
\hline \multicolumn{7}{|c|}{ Survei ke-3 (bulan September sampai dengan Oktober 2005) } \\
\hline $\begin{array}{l}\text { Kabupaten } \\
\text { Pontianak }\end{array}$ & $29,0-31,0$ & $45-60$ & Coklat & $6,0-7,5$ & $4,51-5,91$ & $6,6-11,0$ \\
\hline Kota Pontianak & $29,0-30,0$ & $35-40$ & Coklat & $6,0-6,5$ & $5,37-6,44$ & $6,6-8,8$ \\
\hline $\begin{array}{l}\text { Kabupaten } \\
\text { Sanggau }\end{array}$ & $27,5-29,0$ & $25-40$ & Coklat & $6,0-7,0$ & $5,37-6,44$ & $6,6-9,9$ \\
\hline Kabupaten Sintang & $27,0-29,0$ & $20-35$ & Coklat & $6,0-6,5$ & $5,37-6,44$ & $8,8-9,9$ \\
\hline \multicolumn{7}{|c|}{ Survei ke-4 (bulan Nopember sampai dengan Desember 2005) } \\
\hline $\begin{array}{l}\text { Kabupaten } \\
\text { Pontianak }\end{array}$ & $27,5-30,0$ & $30-55$ & Coklat & $6,3-7,2$ & $5,30-6,06$ & $6,6-9,9$ \\
\hline Kota Pontianak & $27,5-29,5$ & $50-60$ & Coklat & $5,5-6,5$ & $4,90-6,20$ & $7,7-9,9$ \\
\hline $\begin{array}{l}\text { Kabupaten } \\
\text { Sanggau }\end{array}$ & $27,5-29,5$ & $30-40$ & Coklat & $6,0-7,0$ & $5,20-6,20$ & $7,7-9,9$ \\
\hline Kabupaten Sintang & $27,5-29,0$ & $25-35$ & Coklat & $6,0-6,5$ & $5,45-6,30$ & $7,7-9,9$ \\
\hline
\end{tabular}

\section{KESIMPULAN}

1. Penangkapan udang galah (Macrobrachium rosenbergii) di daerah aliran Sungai Kapuas terjadi sepanjang tahun dengan wilayah penangkapan di Sungai Kapuas dan anak-anak sungai mulai dari bagian hilir sampai dengan hulu. Aktivitas penangkapan di bagian hilir (Kabupaten dan Kota Pontianak) lebih dominan dibandingkan dengan bagian hulu (Kabupaten Sanggau dan Kabupaten Sintang). Beragam alat yang digunakan dalam upaya penangkapan udang galah (Macrobrachium rosenbergii) baik yang legal maupun yang termasuk kategori illegal (penggunaan listrik atau stroom) terdapat di perairan daerah aliran Sungai Kapuas. Di bagian hilir alat tangkap yang digunakan adalah pancing (hook and line), rawai udang (long line), jala (cast net), bubu udang (pot traps), jaring (gill net), blad atau empang (barrier traps), romping atau rumpon (surrounding net), pukat rantau (surrounding net), dan alat tangkap menggunakan listrik. Alat tangkap yang sering digunakan di bagian hulu adalah pancing, jala, rawai, bubu, dan jaring atau pukat. Hasil tangkapan udang galah (Macrobrachium rosenbergii) (catch per unit of effort) dengan nilai terkecil terjadi pada 
alat tangkap bubu 1,4 g per unit bubu per jam, terbesar adalah alat tangkap jala dengan nilai catch per unit of effort $416,7 \mathrm{~g}$ per unit jala per jam.

2. Distribusi ukuran panjang udang galah catch per unit of effort yang tertangkap bervariasi dari kecil sampai dengan besar. Pada bagian hilir rata-rata variasi ukuran berkisar antara 11,4 sampai dengan $19,6 \mathrm{~cm}$ di mana nilai modus berkisar antara 9,4 sampai dengan $18,8 \mathrm{~cm}$. Tingkat kematangan gonad pada bagian hilir bervariasi mulai dari tingkat kematangan gonad I sampai dengan IV. Pada bagian hulu, rata-rata distribusi ukuran berkisar antara 12,9 sampai dengan $21,6 \mathrm{~cm}$ dengan nilai modus antara 10,5 sampai dengan $26,0 \mathrm{~cm}$. Distribusi ukuran bobot udang galah (Macrobrachium rosenbergii) pada bagian hilir mempunyai nilai modus yang berkisar antara 17,7 sampai dengan $47,0 \mathrm{~g}$ dan antara 17,8 sampai dengan $85,5 \mathrm{~g}$ pada bagian hulu. Udang galah (Macrobrachium rosenbergii) yang banyak tertangkap termasuk dalam golongan $\mathrm{B}$ (bobot 30 sampai dengan $100 \mathrm{~g}$ ) dan C (bobot $<30 \mathrm{~g}$ ). Kondisi kualitas air daerah aliran sungai Kapuas dalam batasan normal untuk mendukung kehidupan biota air termasuk udang galah (Macrobrachium rosenbergii).

\section{PERSANTUNAN}

Kegiatan dari hasil riset aktivitas penangkapan dan distribusi udang galah (Macrobrachium rosenbergii) di Kalimantan Baratzsc. T. A. 2005, di Balai Riset Perikanan Perairan Umum-Mariana, Palembang.

\section{DAFTAR PUSTAKA}

APHA. 1988. Standart method for the examination of water and wastewater. $15^{\text {th }}$ Edition. American Public Health Association. Washington, D. C. 1.134 p.

Badan Perencana Pemerintah Daerah Kalimantan Barat. 2002. Pemetaan liputan lahan Propinsi Kalimantan Barat. Laporan Akhir Pusat Survei Sumber Daya Alam Bakosurtanal dengan Badan Perencana Pemerintah Daerah Kalimantan Barat. 63 hal.
Brandt, A. V. 1969. Application of observation on fish bahaviour for fishing methods and gear construction. FAO Fisheries Reports, Rome. P 169-191.

Boyd, C. E. 1979. Water quality in warmwater fishponds. Auburn University. Depart of Fisheries and Alied Aquaculture. First Edition. Alabama. USA. 359 p.

Dinas Kelautan dan Perikanan Tingkat I Kalimantan Barat. 2003. Statistik perikanan Propinsi Kalimantan Barat. Pemerintah Propinsi Kalimantan Barat. Dinas Kelautan dan Perikanan. Pontianak. 97 hal.

Mantel, L. H. 1983. The biology of crustaceae. Internal anatomy and physiological regulation. Academic Press. New York. 5. 1-26.

NTAC. 1968. Water quality criteria. FWPAC. Washington, D. C. 234 p.

Ritonga, A. 1987. Statistika terapan untuk penelitian. Lembaga Penerbit Fakultas Ekonomi Universitas Indonesia. Jakarta. Indonesia. 379 hal.

Samuel, S. Adjie, \& A. D. Utomo. 1991. Aspek biologi dan ekologi udang galah (Macrobrachium rosenbergii) di Sungai Lempuing, Sumatera Selatan. Buletin Penelitian Perikanan Darat. Vol.10. No.2 (Juni 1991). Balai Penelitian Perikanan Air Tawar. Bogor. Hal.: 32-39.

Utomo, A. D. 1997. Perikanan udang galah (Macrobrachium rosenbergii) di Sungai Lempuing, Sumatera Selatan. (unpublished). Loka Penelitian Perikanan Air Tawar. Palembang. 16 hal.

Utomo, A. D., K. A. Azis \& I. Muchsin. 2002. Ruaya udang galah (Macrobrachium rosenbergii) dan kegiatan penangkapan dengan alat tuguk di Sungai Lempuing, Sumatera Selatan. Jurnal IImu-IImu Perairan dan Perikanan Indonesia. (2002). IX (1). 1-12 Fakultas Perikana.n Institut Pertanian Bogor. Bogor. Hal.:1-12.

Welcomme, R. L. 1979. Fisheries ecology of flood plain rivers. Longman. London and New York. 106136. 